\title{
Cave to mill: improving value of caving operations
}

\author{
A Moss The University of British Columbia, Canada \\ B Klein The University of British Columbia, Canda \\ S Nadolski The University of British Columbia, Canada
}

\begin{abstract}
Forecasts indicate that there will be an increase in copper production from underground operations over the coming decades as available resources trend deeper. It is anticipated that a significant portion of this production will be from caving operations. Caving has a very different risk profile to open pit mining and other underground methods, with one of the critical areas being run-of-mine (ROM) grades that are delivered to the mill. Though caving can match pits in terms of operating cost per tonne, it suffers from limited grade selectivity with ROM grades trending toward the orebody average due to the consequences of mixing in cave columns. Research and subsequent operational trials have demonstrated that bulk sorting can manage this lack of selectivity by 'pre-concentrating' the ROM ore, providing the mill with a more consistent and higher grade feed.

The paper describes the 'cave to mill' concept where the objective is to provide consistent feed (tonnes and grade) to the flotation circuit. This is done in three stages. The first stage is better characterisation of the material reporting to drawpoints. Secondly, measurement of the variation in metal content that is delivered from drawpoints through the use of scanners and sensors at various points in the ore flow system. Finally, bulk sorting systems offer flexibility and control by allowing classification of waste, low-grade and mill-grade streams in real time. The potential for bulk sorting is dependent on the heterogeneity of the ore and the ability of sensors to detect the heterogeneity. The broad technical requirements for each stage are discussed together with the associated business case.
\end{abstract}

Keywords: block cave mining, grade control, cave to mill, sensor-based sorting

\section{Introduction}

Projections for copper demand indicate up to a $350 \%$ increase by 2050 , at which time demand will exceed reserves (Elshkaki et al. 2016). The absence of new discoveries means that the mining industry will need to develop lower grade deposits at depth. Decreasing copper grades requires that mining operations must take advantage of economies of scale. Block caving is the only mining method that can be practically applied to the large low-grade deposits at depth in order to supply future copper demand.

Block caving is inherently a non-selective mining method. Operations maintain control of the cave by managing ore withdrawal through the drawpoints. Within the constraints of maintaining the caving operation, the only means of controlling grade is by blending, which often includes mixtures of barren host and low-grade waste. Advances in sensor-based systems allow grade estimation at the bulk scale (Scantec 2018; MineSense 2018a, b). Systems have been developed that can monitor grades at drawpoints, in shovels and on conveyors.

Critical to developing suitable bulk sorting systems is knowledge of the variability horizontally across and vertically along drawpoints, which represents the heterogeneity. The orebody model indicates the variability, but predictions of drawpoint grade are complicated by mixing in the cave. Characterising orebody heterogeneity and understanding how this translates into grade at the drawpoints is needed. 


\section{Economics of cave mining}

Several trends (Figure 1) are evident in copper mining, including:

- Increases in metal demand.

- Key pit operations reaching maturity.

- Reserves being depleted at a faster rate than they are currently being replenished, increasing pressure to mine lower head grades.

- New ore discoveries trending deeper (Figure 1).
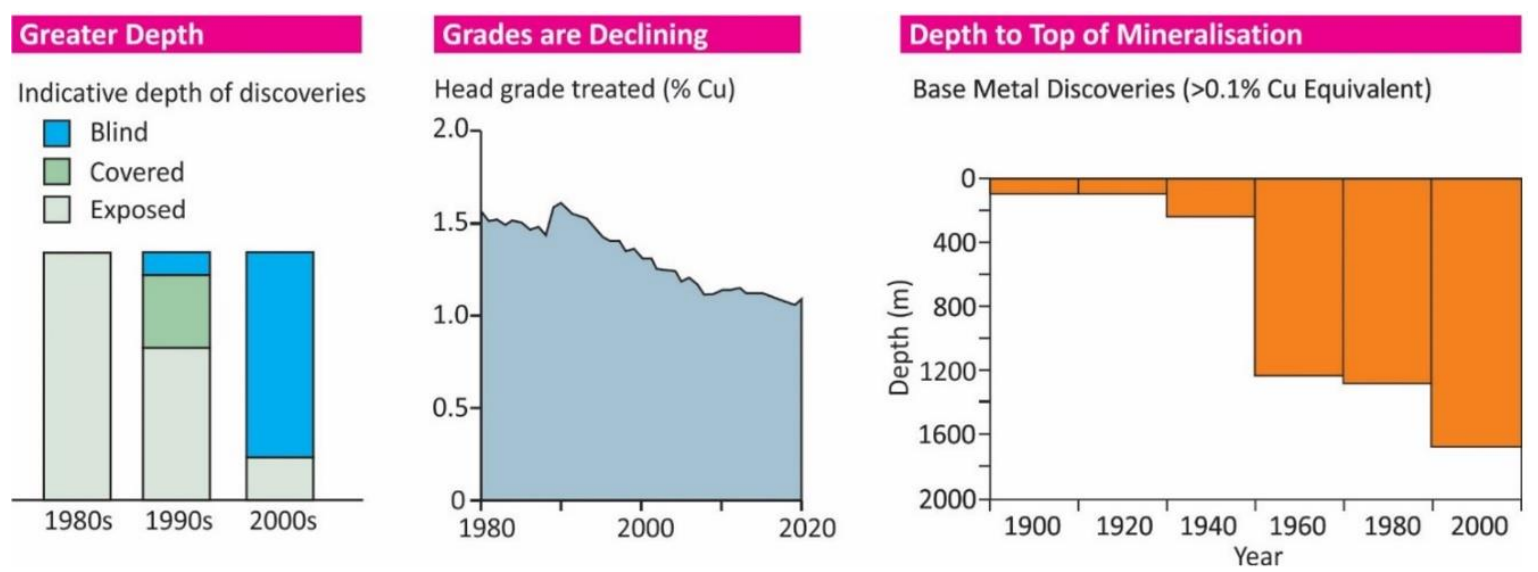

Figure 1 Mining trends in copper production (developed from published data)

These trends will drive an increase in underground production using methods that can achieve the economies of scale required to deal with declining grades and the increased costs associated with underground mining. Thus, caving, though an old method, is having a new lease of life due to key characteristics:

- Bulk, non-selective method suitable for large low-grade orebodies.

- Lower operating costs than other underground methods and, potentially, comparable with, or lower than, those of open pits.

- Ability to achieve high productivity per underground employee compared with other mining methods.

- Capable of automation to produce the underground ore factory.

Caves are large, capital-intensive operations (Figure 2(a)) that must be justified by a good understanding of the major value drivers - orebody knowledge, mine design and management. A focus on capital has led to changes in cave layouts with the advent of high-lift caves and increased drawpoint spacing. The outcome of these design changes is uncertain due substantially to limited understanding of key caving processes, such as fragmentation and draw behaviour. Figure 2(b) shows a grade proxy for revenue changes over time at one operation. While indeed the appropriate course of action may be capital efficiency, it is important to understand the value proposition in terms of risks and likely outcomes. 


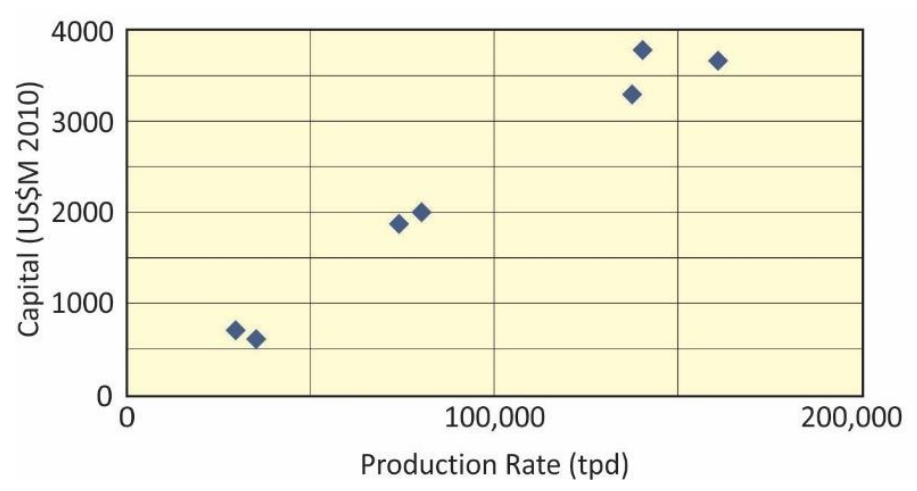

(a)

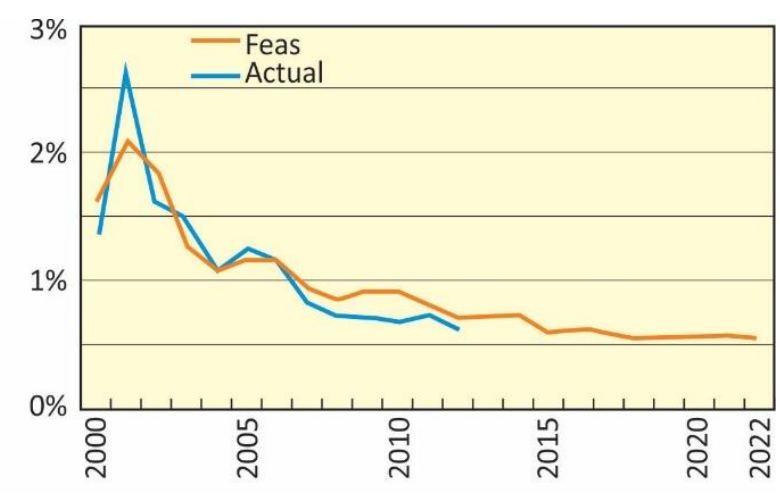

(b)

Figure 2 (a) Capital costs versus production rates for caving operations; and, (b) Typical Cu grades versus time

\section{Cave to mill}

According to Albanese and McGagh (2011), "caves should be considered to be "rock factories" - mines built to a specified quality and schedule - and then operated in a predictable manner in terms of production rate, grade and costs". However, what should be clear is that a cave is materially more complex than an open pit or other underground methods, with a marked difference in the risk profile. This is due to upfront capital requirements, the lengthy construction period, the often imperfect orebody knowledge and the limited grade selectivity due to the draw process. Thus, the concept of an ore factory is very important with an implicit need to shift thinking from the current reactive approach focused on elements of the mine to a reliability approach where the mine and the mill is an integrated system (Figure 3). This is the basis for a cave to mill' strategy based on comprehensive orebody knowledge and real-time measurements of ore characteristics from drawpoint to mill, providing information on grade from drawpoint to crusher to stockpile to mill.

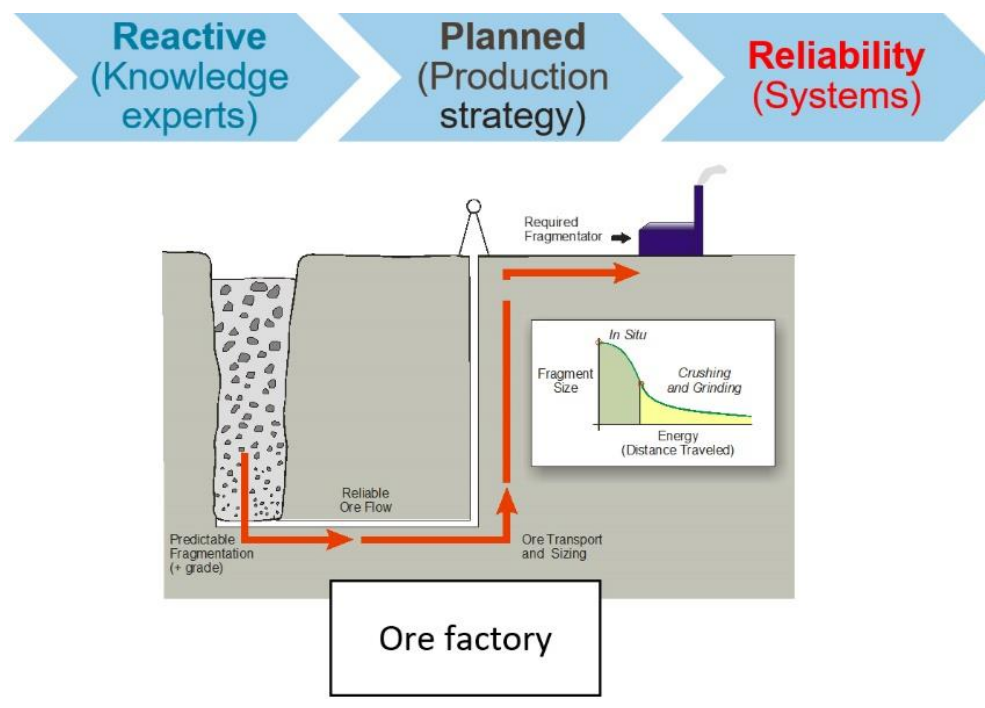

\section{Figure 3 Ore factory concept}

Fundamental to this understanding of the costs of caving operations is insight into the mechanics of caving (propagation, fragmentation and flow), the reliability of the cave footprint (undercut, extraction and haulage levels), and ultimately the quantity and quality of the product delivered to the mill (Figure 3). Unlike surface or other underground methods, a cave is dynamic. In other mining methods, a specific block of ore does not move prior to drilling and blasting. Notwithstanding errors in the resource model, the prediction of ore grade and dilution is straightforward. In a cave, the orebody must fragment and move. With cave heights $>500 \mathrm{~m}$, forecasting the production grade at each drawpoint not only depends upon the 
original grade distribution of the orebody but also on how the fragmented rock is drawn down the column relative to surrounding rocks. This represents a significant risk, as our ability to forecast how the ore fragments and moves to the drawpoints is limited.

The descriptor 'cave to mill' was developed from the concept of 'mine to mill' which focused on rock fragmentation via drilling and blasting to increase mine productivity. Cave to mill (Nadolski et al. 2015) is aimed at reflecting a broader range of operational considerations with a focus on exploiting opportunities from an integrated mining and processing system with all the considerations of the 'rock factories' and the goal of increasing block cave project value (Figure 4).

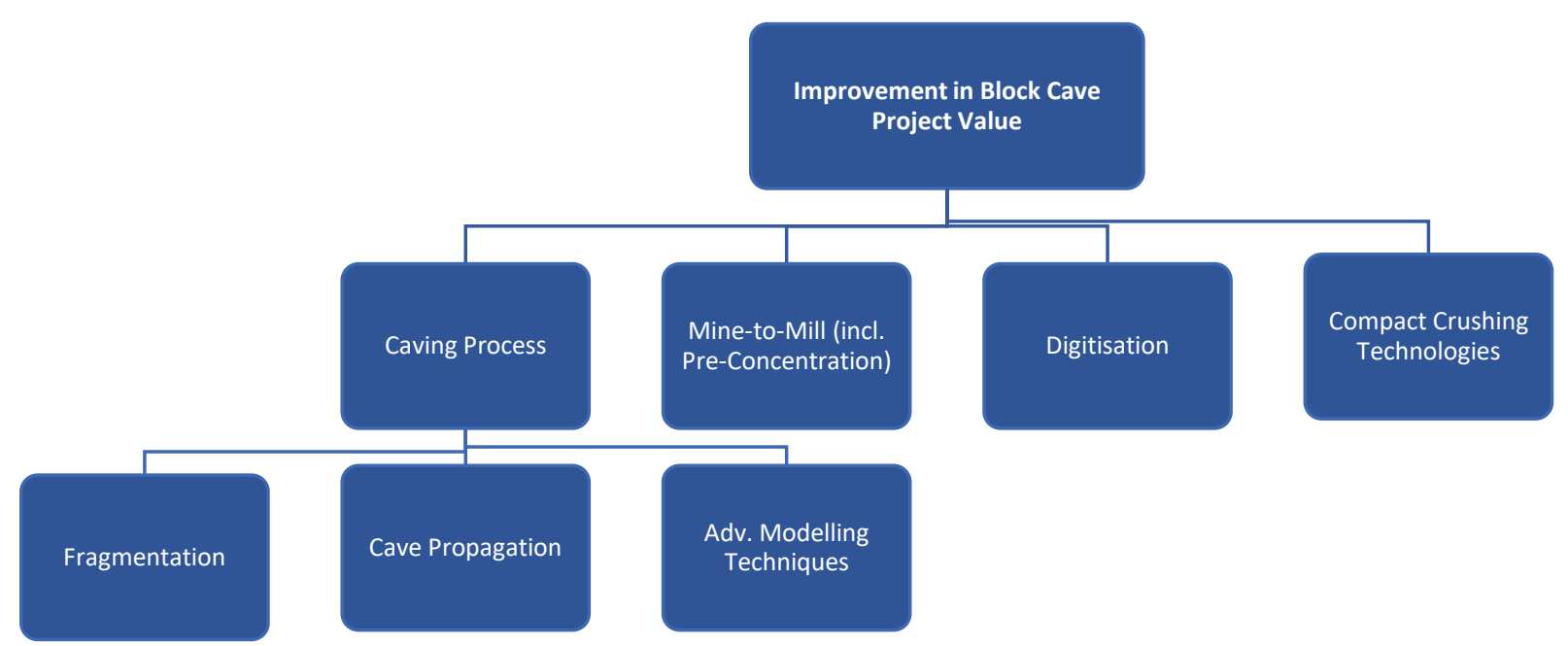

Figure 4 Cave to mill - contributors to block cave value

To advance the cave to mill concept, research and development has been focused into four main areas:

- Orebody knowledge: Improved characterisation of rock mass properties and behaviour for improved support design and more accurate prediction of cave propagation, fragmentation and processing.

- Mine-mill integration: Integration of processes to enhance mine and mill performance.

- Preventative support maintenance: Targeting reductions in damage-related production interruptions.

- Sensor-based sorting: Evaluation of bulk- and particle-sorting systems for integration with underground mobile equipment and material-handling systems.

\section{Assessment of bulk sortability}

Caving is an inflexible process with limited opportunity for grade uplift through the selection processes commonly found in pits. Recovered grades in caving is very much a function of how the ore fragments, flows and mixes in the draw columns prior to reporting to the various drawpoints. From the drawpoints, the ore is transferred to an ore handling system where further mixing occurs. There is a tendency for grades to revert to mine average, or lower, due to these processes as illustrated in Figure 2(b). The lower grades delivered to the mill ultimately affect the value proposition. The opportunity exists, however, for bulk sorting by enhancing orebody knowledge and adopting a comprehensive mine to mill measuring system, providing a key to releasing value and enhancing the robustness of marginal operations.

The potential to apply sorting depends on the properties of the ore as well as the ability of sensors. There are four components to assessing the sortability of ore (Figure 5) including heterogeneity analysis, sensor evaluation, sorting analysis and feasibility. 


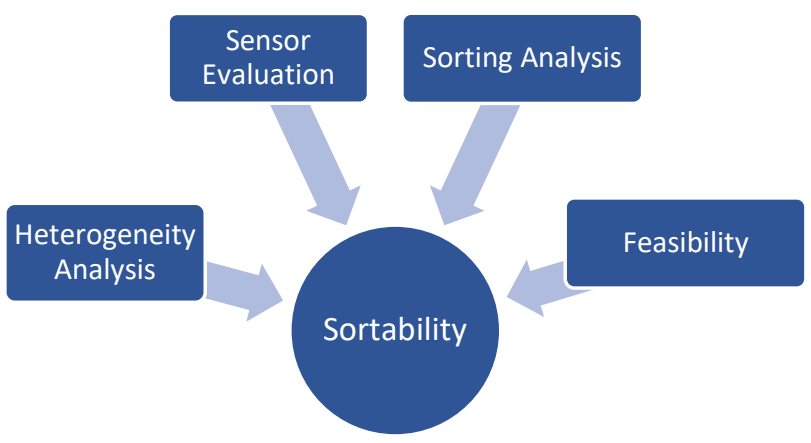

Figure 5 Sortability of ores (Klein \& Bamber 2018)

\subsection{Heterogeneity analysis}

Heterogeneity is a prerequisite to sorting; if the orebody is homogeneous, there is no opportunity for sorting. In reality there are few, if any, examples of homogeneous orebodies. The degree and scale of heterogeneity indicate the potential benefits. Heterogeneity can be at the particle scale that ranges from microns, where comminution liberates minerals increasing the heterogeneity for separation processes such as flotation; to tens of $\mathrm{cms}$ that allow sensor-based particle sorting or processes such as dense media separation. Heterogeneity at the bulk scale can exist in increments from tens of kilograms to 1,000 s of tonnes. Bulk heterogeneity is related to in situ spatial heterogeneity as a consequence of variations between lithological units and host rocks. Another form of heterogeneity that has been investigated is heterogeneity by size class, referred to as 'grade engineering'. Due to variations in hardness, fragmentation from caving and transport to the drawpoints can concentrate the valuable constituents into size classes (McKee et al. 1995). While softer metal-bearing sulphide minerals are often concentrated into fine particle size classes, hard competent barren rock will resist breakage. This usually results in a grade uplift during the earlier phases of caving where fine higher grade particles percolate through the muck pile.

Figure 6 presents heterogeneity data from a drawpoint of a block cave mine. Drawpoints are sampled at approximately $400 \mathrm{t}$ increments. Therefore, the responses represent the heterogeneity with respect to bulk sorting at the $400 \mathrm{t}$ scale. The grade histograms indicate that about $25 \%$ of the ore has a grade lower than about $0.2 \% \mathrm{Cu}$. The metal distribution and grade versus mass yield plot shows that $50 \%$ of the mass contains $90 \%$ of the copper. Also, by rejecting $50 \%$ of the mass representing a $10 \%$ copper loss, the grade of ore to the mill is increased from the average drawpoint grade of about $0.2 \%$ to about $0.4 \%$.

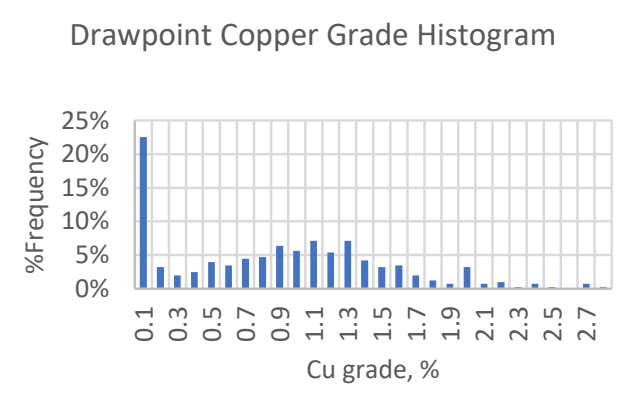

(a)

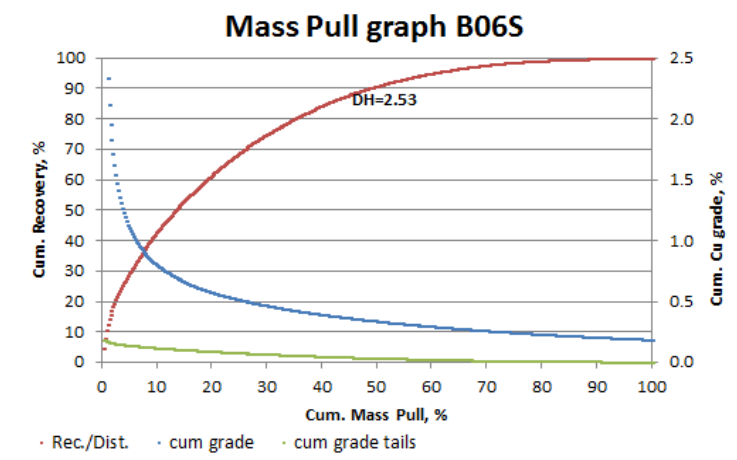

(b)

Figure 6 (a) Grade histogram; and, (b) Recovery and grade versus mass pull curves for ore from a drawpoint at a block cave (Erdenebat 2017) 
Gy (1995) defined spatial heterogeneity as the distribution heterogeneity (DH) according to the following equation:

$$
\mathrm{DH}=\mathrm{N}_{\mathrm{g}} *\left(\Sigma\left(\mathrm{a}_{\mathrm{i}}-\mathrm{a}_{\mathrm{L}}\right)^{2} \times \mathrm{M}_{\mathrm{i}}{ }^{2}\right) /\left(\mathrm{a}_{\mathrm{L}}{ }^{2} \times \mathrm{M}_{\mathrm{L}}{ }^{2}\right)
$$

where $\mathrm{N}_{\mathrm{g}}$ is the number of groups, $a_{i}$ and $a_{L}$ are the grades of group $i$ and the lot, respectively, while $M_{i}$ and $M_{L}$ are the masses of group $i$ and the lot. The lot is a special domain that can represent an entire draw column, in the case that heterogeneity within an individual drawpoint is being assessed, or a horizontal slice of caved ore, in the case that heterogeneity during a period of mine production is being determined.

A high DH indicates a high potential for rejection of low-grade material while maintaining a high metal recovery. As per Figure 6 , the $\mathrm{DH}$ for the block cave drawpoint was 2.53 , indicating good potential. Figure 7 presents the $\mathrm{DH}$ values from more than 250 drawpoints at the $400 \mathrm{t}$ scale. The plot shows that the $\mathrm{DH}$ values increase with decreasing grade from less than 0.1 at a Cu grade of $1.5 \%$ to almost 10 at a grade of $0.1 \%$. In this case, drawpoints with low average copper grades exhibit a higher degree of heterogeneity and, therefore, sortability. In such a case, bulk sorting could focus on material from low-grade drawpoints. Low-grade drawpoints may be located at the fringes of the deposits, which would be explained by dilution with the host rock. An operating strategy to sort the ore at the fringes where the low DH values are observed has potential to reject and divert significant amounts of material away from the process plant. Alternatively, ore from drawpoints more centrally located would not require sorting.

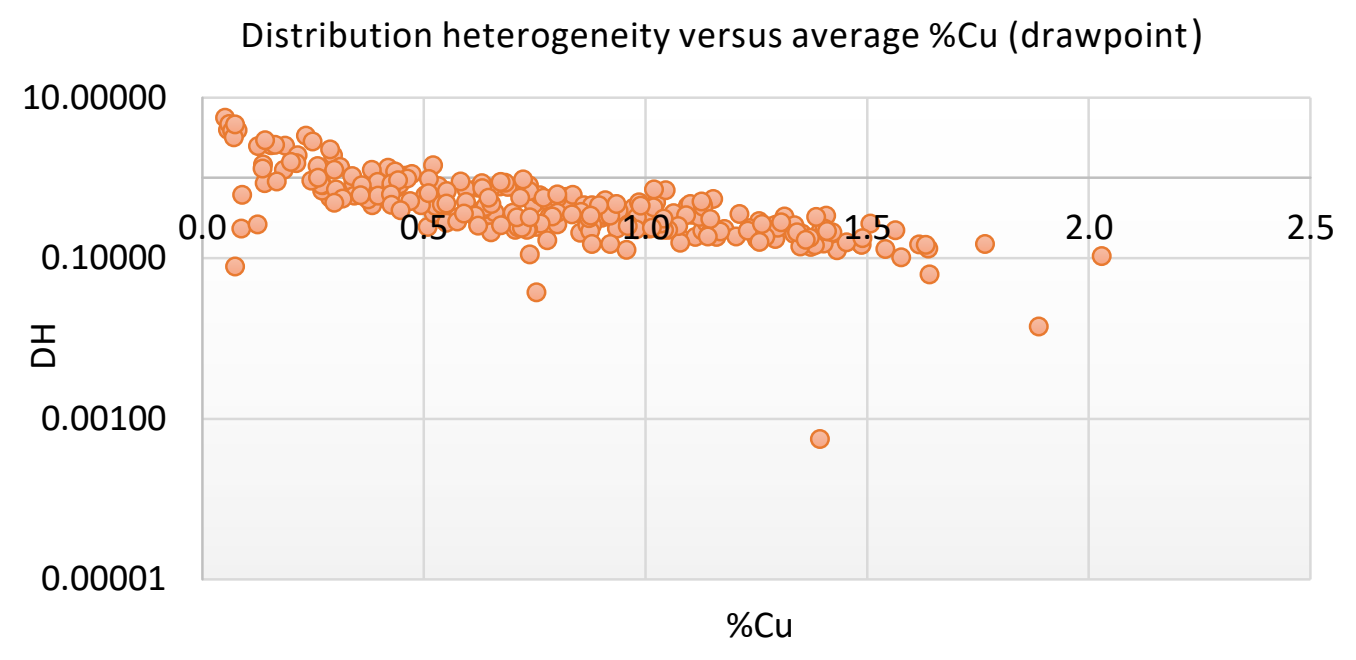

Figure 7 Plot of DH versus average drawpoint copper grade

The in situ heterogeneity can be characterised from drill core data to indicate the potential for sorting. As caved ore is transported to the drawpoints, there is a loss of heterogeneity due to mixing. Blending practices and mixing along the material-handling chain further reduce heterogeneity (Table 1). Therefore, sorting as close to the mining activity as possible has the best potential for bulk sorting. The integration of either shovel sensing systems that range in size from load-haul-dumpers (LHDs) for underground operations to large-scale shovels for open pit mines or conveyor belt sensing systems can be employed. There is an opportunity to review blending and campaigning practices to best take advantage of the sorting systems. 
Table 1 Chronological mixing/comminution events and their impact on heterogeneity (Nadolski et al. 2016)

\begin{tabular}{|c|c|c|c|c|}
\hline \multirow[t]{2}{*}{ Chronology } & \multirow{2}{*}{$\begin{array}{l}\text { Blending/comminution } \\
\text { event }\end{array}$} & \multirow{2}{*}{$\begin{array}{l}\text { Blending or } \\
\text { comminution event }\end{array}$} & \multicolumn{2}{|c|}{ Impact on heterogeneity } \\
\hline & & & $\begin{array}{l}\text { Constitutional } \\
\text { heterogeneity }\end{array}$ & $\begin{array}{l}\text { Distributional } \\
\text { heterogeneity }\end{array}$ \\
\hline 1 & Fragmentation at cave back & $\begin{array}{l}\text { Fragmentation } \\
\text { (primary) }\end{array}$ & & - \\
\hline 2 & $\begin{array}{l}\text { Collapse onto caved ore } \\
\text { muck pile }\end{array}$ & $\begin{array}{l}\text { Blending and minor } \\
\text { fragmentation }\end{array}$ & 4 & \\
\hline 3 & Waste entering draw cones & $\begin{array}{l}\text { Blending (new ore } \\
\text { type generated) }\end{array}$ & - & \\
\hline 4 & Flow through draw cones & $\begin{array}{l}\text { Blending and } \\
\text { secondary } \\
\text { fragmentation }\end{array}$ & & \\
\hline 5 & $\begin{array}{l}\text { Haulage to orepass (through } \\
\text { grizzly) }\end{array}$ & $\begin{array}{l}\text { Blending and minor } \\
\text { fragmentation }\end{array}$ & & \\
\hline 6 & Mixing in orepass & Blending & - & \\
\hline 7 & Primary crushing & $\begin{array}{l}\text { Mechanical } \\
\text { comminution }\end{array}$ & & - \\
\hline 8 & $\begin{array}{l}\text { Material flow through } \\
\text { crusher product silo }\end{array}$ & Blending & - & \\
\hline 9 & $\begin{array}{l}\text { Material transport to surface } \\
\text { stockpile }\end{array}$ & Minor blending & - & \\
\hline 10 & Flow through stockpile & Blending & - & \\
\hline
\end{tabular}

\subsection{Sensor evaluation for bulk sorting}

The second component of assessing sortability is to evaluate the ability of sensors to detect the heterogeneity. Several sensor systems have been developed that correlate sensor response to metal grade at levels that are suitable for control systems. Numerous sensors have been developed for particle sorting, but only subsets have been developed for bulk sorting, such as in shovels and on conveyors (Table 2).

There are several approaches to using sensor data to classify ores:

- Correlate sensor response to actual grade.

- Combining sensor responses to improve accuracy.

- Analysis of proxies for target metals or minerals.

- Assessing heterogeneity of gangue phases for rock rejection - i.e. detect the waste for rejection.

- Apply regression analysis or artificial intelligence to develop models to selected grade ranges. 
- Assessing scale of heterogeneity to determine increment size suitable for a bulk sorting system, such as tens of kgs to hundreds of tonnes.

Table 2 Sensors for bulk sorting (Klein \& Bamber 2018)

\begin{tabular}{|c|c|c|c|c|}
\hline Technology & Physical property & Principle & $\begin{array}{l}\text { (Surface/ } \\
\text { volume) }\end{array}$ & Ore types \\
\hline $\begin{array}{l}\text { Radiometric } \\
\text { (scintillometer) }\end{array}$ & $\begin{array}{l}\text { Natural gamma } \\
\text { radiation }\end{array}$ & Radioactivity & Volume & $\begin{array}{l}\text { Uranium, } \\
\text { Witwatersrand gold ores }\end{array}$ \\
\hline PGNAA, PFTNA & $\begin{array}{l}\text { Elemental } \\
\text { composition }\end{array}$ & $\begin{array}{l}\text { Neutron } \\
\text { activation/ } \\
\text { gamma } \\
\text { emission }\end{array}$ & Volume & $\begin{array}{l}\text { Iron ore, base metals, } \\
\text { coal, manganese, } \\
\text { phosphate }\end{array}$ \\
\hline $\begin{array}{l}\text { X-ray fluorescence } \\
\text { spectroscopy (XRF-S) }\end{array}$ & $\begin{array}{l}\text { Elemental } \\
\text { composition }\end{array}$ & $\begin{array}{l}\text { Inner shell } \\
\text { electron } \\
\text { excitation }\end{array}$ & Surface & $\begin{array}{l}\text { Base/precious metals, } \\
\text { metal sulphides }\end{array}$ \\
\hline $\begin{array}{l}\text { Laser fluorescence/ } \\
\text { X-ray fluorescence }\end{array}$ & $\begin{array}{l}\text { Visible } \\
\text { fluorescence } \\
\text { under X-ray/laser } \\
\text { stimulation }\end{array}$ & Fluorescence & Surface & $\begin{array}{l}\text { Diamonds, limestone, } \\
\text { iron ore, sulphides }\end{array}$ \\
\hline Electromagnetic (EM) & $\begin{array}{l}\text { Conductivity/ } \\
\text { magnetic } \\
\text { susceptibility }\end{array}$ & $\begin{array}{l}\text { Electromagnet } \\
\text { ism/induction }\end{array}$ & Volume & $\begin{array}{l}\text { Base metals, native } \\
\text { metals, metal sulphides, } \\
\text { massive oxides }\end{array}$ \\
\hline
\end{tabular}

Note: PGNAA = prompt gamma neutron activation analyser

There are several approaches to using sensor data to classify ores:

- Correlate sensor response to actual grade.

- Combining sensor responses to improve accuracy.

- Analysis of proxies for target metals or minerals.

- Assessing heterogeneity of gangue phases for rock rejection - i.e. detect the waste for rejection.

- Apply regression analysis or artificial intelligence to develop models to selected grade ranges.

- Assessing scale of heterogeneity to determine increment size suitable for a bulk sorting system, such as tens of kgs to hundreds of tonnes.

For bulk sorting, the sensor systems have been integrated into the material-handling equipment. Sensors have been mounted on shovels (Figure 4) and on conveyor belts (Figure 5). The information from the sensors can be used for decision-making, including feed forward control or diversion. For feed forward control, information can inform the process plant on operational considerations such as throughput, comminution requirements or reagent dosage. For grade control, systems that divert ore according to grade can be implemented.

Shovel sensing systems that use X-ray flourescence to estimate the grade of ore in the shovel have been developed by MineSense Technologies Ltd. The sensor response can be displayed to the shovel operator such that, based on a threshold, the decsion can be made to load to a waste truck or an ore truck. For open pit operations, fleet dispatch systems need to support the flexibility with two haulage trucks in place. For underground mines such as block caves, the shovel sensing system enables an estimation of copper grade at each drawpoint in real time. An integrated system that allows exploitation of this information requires flexibility in the mine design. With this flexibility, mine strategies may be different than present goals of blending to a 
target mill feed. For example, while ore with sufficient grade can report directly to the plant feed, low- or marginal-grade material can be campaigned to low-grade stock piles. Figure 8 shows the results of a pilot-scale study at a copper mine using an $8 \mathrm{t}$ shovel. The shovel sensing system was able to predict copper grades in $8 \mathrm{t}$ increments to within $+/-0.05 \%$ from stock piles grading between about 0.05 to $0.30 \%$.
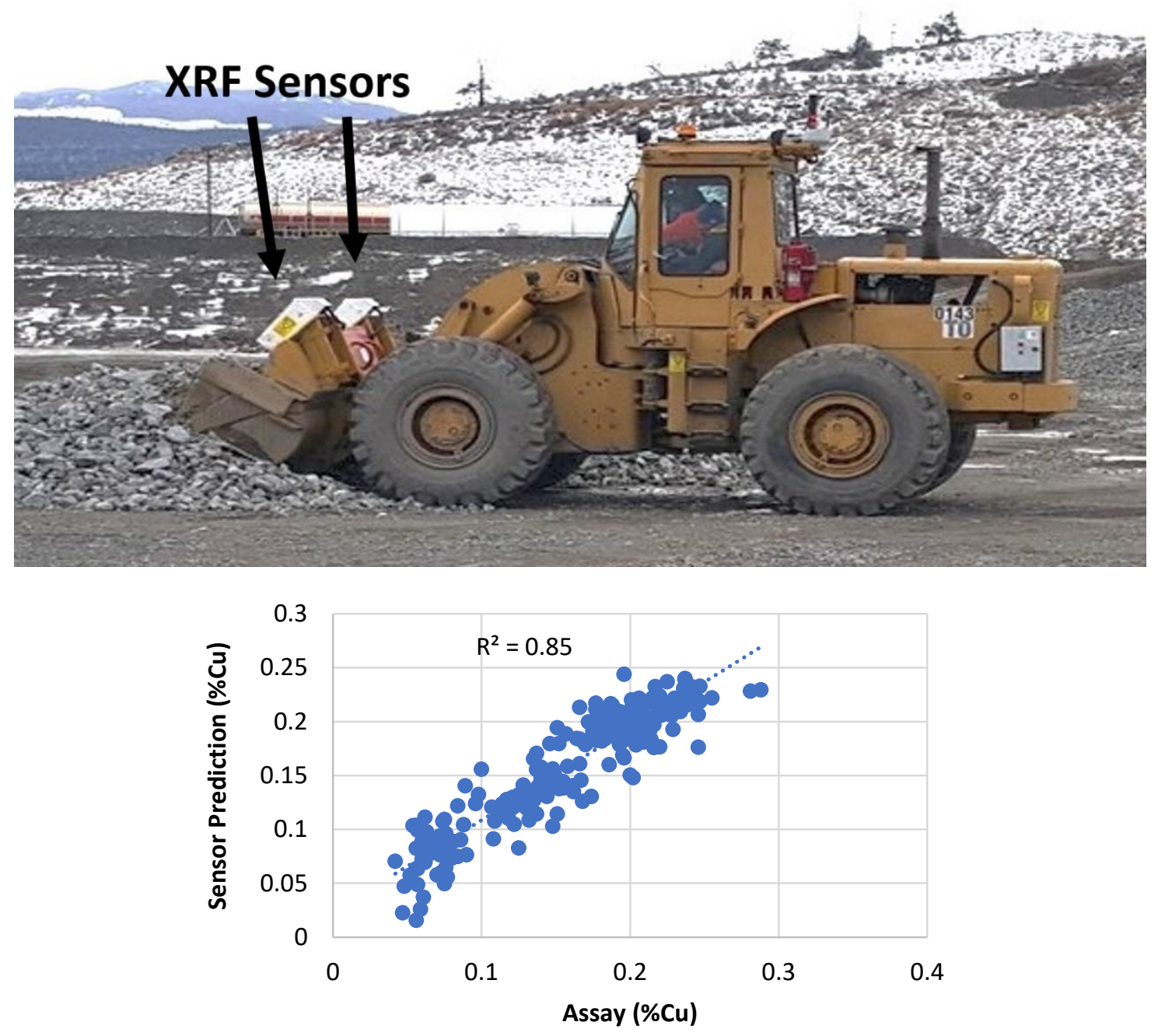

Figure 8 Shovel sensing system with XRF mounted on shovel and plot of predicted grades versus assayed grades (Hengemuhle et al. 2017)

Similarly, belt-mounted sensors can track ore quality from the shovel to the grinding circuit (Figure 9). Belt mounted sensors can compare the sensor response to a threshold to actuate deflector systems. Figure 9 shows a PGNAA mounted on a conveyor belt as well as a control system to divert the ore to different conveyors according to grade. Such a system was installed at the New Afton Mine. One proposed plan would be to classify primary crusher product from the underground block cave into high-grade, low/marginal-grade and waste products. The high-grade ore would report to the process plant, the low-grade ore to a stockpile, and the waste to a waste dump. Low-grade ore could then be subjected to a particle sorting system to reject baren rock and upgrade the metal content to feed the process plant. 

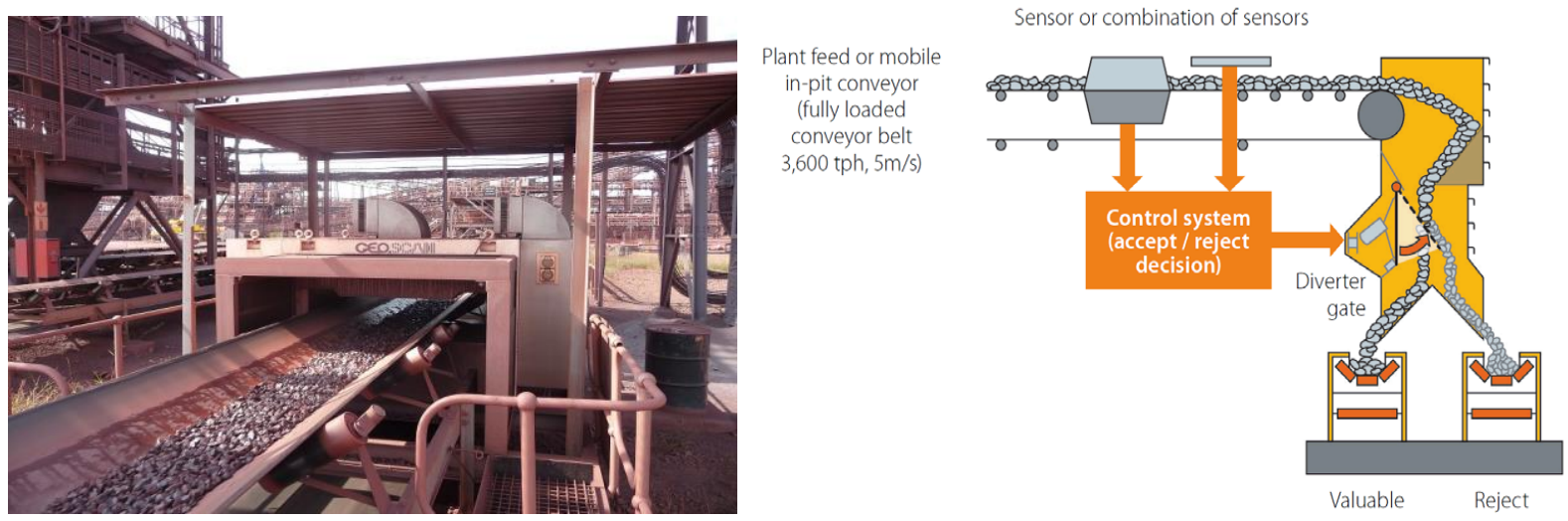

Figure 9 PGNAA elemental and moisture analyser installation for iron ore (Kurth 2017) integrating bulk ore sorting into a mining operation to maximise profitability (Duffy et al. 2015)

To assess the PGNAA system, in collaboration with the New Afton Mine, The University of British Columbia selected different rock types and blends for training and calibration of the PGNAA test unit. The calibrated model was then tested against a set of blind samples to demonstrate the accuracy. Figure 10 shows good correlation of the $\mathrm{Cu}$ grades and Au grades.
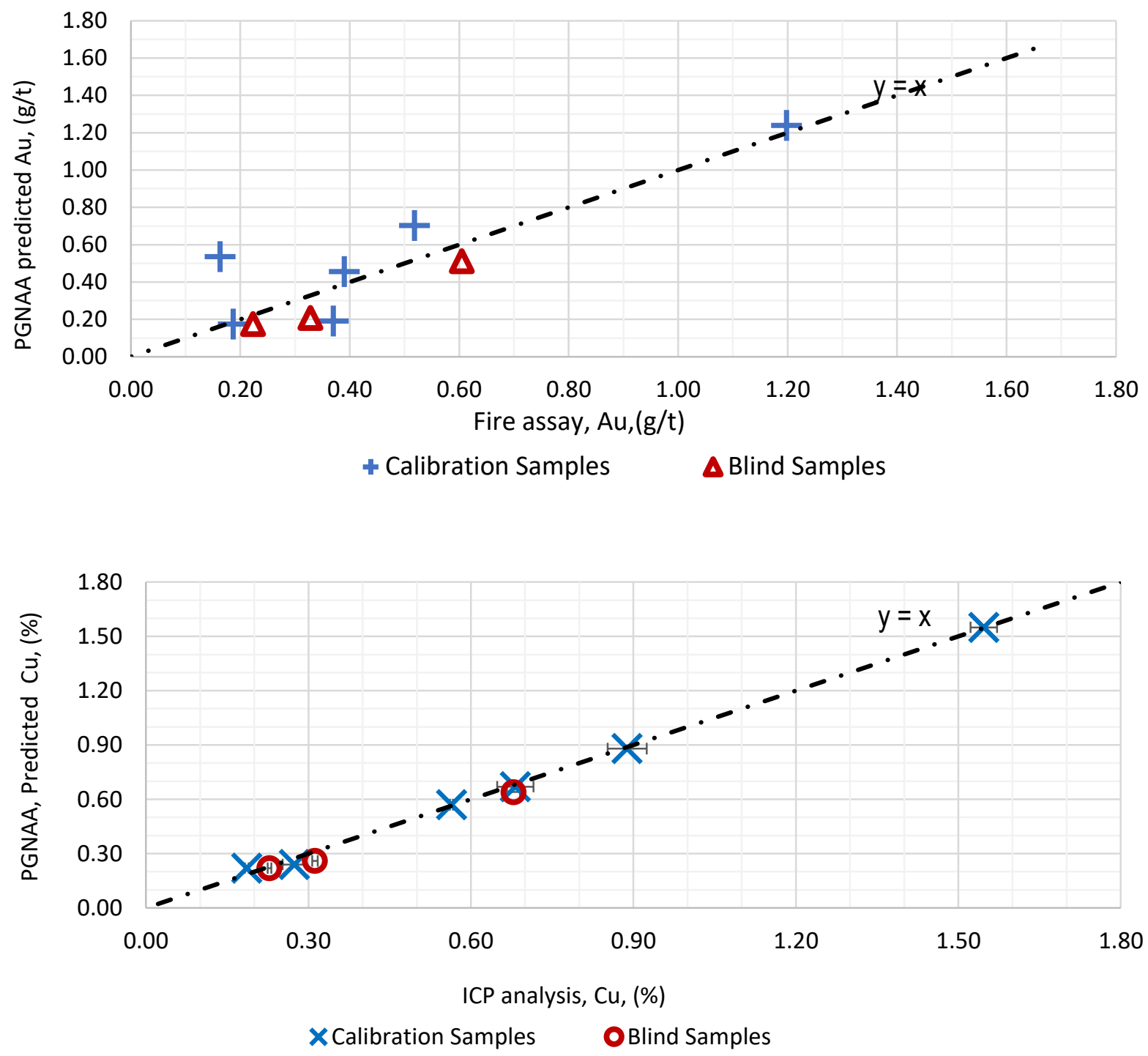

Figure 10 Predicted gold and copper grades of bulk samples using PGNAA sensors (Nadolski et al. 2017) 


\subsection{Cave to mill system design}

Strategies for bulk sorting are specific to the orebody geology and the mining operation. Within the deposit, variations in lithological ore types and contacts between ore and waste rock will offer different opportunites for sensor-based sorting. Some considerations include:

- The integration of the sorting system into existing upstream and downstream circuits.

- Ancillary equipment required, such as for feed preparation, product stream-handling.

- Operational issues related to operating performance, maintenance and training/expertise.

As described above, heterogeneity decreases from the cave through to the process plant feed conveyor due to mixing. Therefore, a bulk sorting system located close to the drawpoints has the greatest potential for benefit to the operation. A shovel sensing system on LHDs would require additional underground infrastructure to handle a waste stream in parallel to an ore stream. However, knowledge of the three-dimensional heterogeneity along with the ability to determine grades at the drawpoints in real time may inform campaigning strategies. Drawing material at the fringes, where dilution is known to be of the highest grades, can be addressed in the mine plan. Production from such areas can be campaigned such that a belting sensing/sorting system can divert waste at the surface.

At the New Afton Mine, a PGNAA sensor was installed on the conveyor tranpsorting ore to the surface (Figure 11). The envisaged process uses a combination of bulk- and particle-sorting systems. The caved material is conveyed to surface where a PGNAA bulk sensor classifies the material into high-grade, intermediate-grade and waste materials using a diverter system. High-grade is transported to the process plant and waste to a waste dump. The intermediate-grade material is fed to a screening plant for preparation of material for particle sorting. Sorting product is sent to the process plant and rejected rock to the waste dump. Based on grades, fine material from the screening plant can be sent to the process plant or the waste dump.

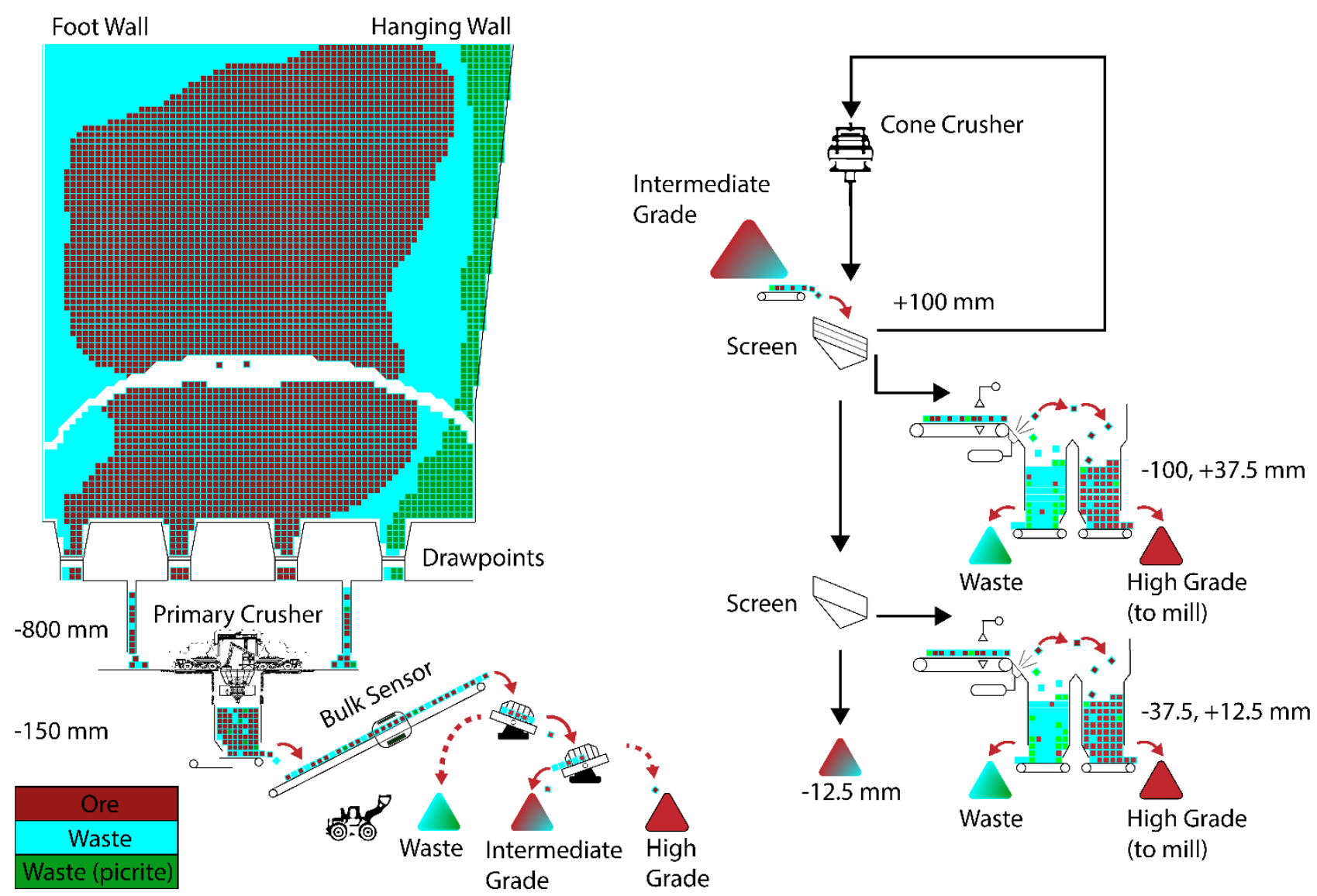

Figure 11 Simplified flow sheet of the mine and sorting systems (Nadolski et al. 2017) 
Such a system increases the grade to the downstream comminution and downstream processing plant and can thereby increase overall metal production. For ore from higher grade drawpoints, rejection may be small, but based on the ore heterogeneity and for drawpoints such as that presented in Figure 6, grades can be increased by $100 \%$, from 0.2 to $0.4 \%$, with less than $10 \%$ loss in Cu recovery. Another important benefit is the energy savings by not grinding the rejected material.

\section{Summary}

Available data indicates that around $10 \%$ of the world's copper production will be from caving operations by the early 2020s; increasing to about $25 \%$ over the following decade as open pits become exhausted and are replaced by bulk underground operations. However, comments by Peele (1918) are as relevant today as they were at the beginning of the last century:

"Block-caving, where applicable, gives a lower mining cost than any other underground method. It is essentially for large scale work. In its different forms, it is applicable to deposits of various shape and to ores of various strength, but has rigid requirements and limitations. In unsuitable deposits, or where carelessly conducted, the loss of ore may exceed that of any other method; systematic work, careful supervision, and good judgment are essential to success."

Thus, cave projects need to be financially robust to address known and unknown risk events. Analysis indicates that incentive pricing of USD 3.00 to 3.50 per lb is required to bring many of the currently proposed caving projects into production. This suggests that a change in the overall approach to caving is required using technology to increase the margins and to de-risk the project.

Block caving inherently lacks selectivity, resulting in both ore and waste being transported for processing. Sensor-based sorting systems provide an opportunity to discriminate between grades enhancing the level of selectivity and thereby improving mine productivity. Considerations of bulk-sorting systems include:

- Ore characterisation: The level and the extent to which the orebody should be characterised, with respect to its heterogeneity and its variability across the geo-metallurgical domains that might exist in the mineral deposit.

- Sorting amenability: The amenability of the orebody over the life of the mine to sorting technologies and their designed duty to differentiate either separate particles or bulk materials with a specified sorting parameter or proxy measurement.

- Economics of sensor-based sorting: The robustness of the techno-economic business case during project evaluation and the sensitivity to factors such as variations in ore geology.

- Sorting technologies - capabilities and limitations: The technology capabilities and limitations with respect to sensors, mechanical separation, throughput and particle size.

- Sorting system design and integration: The integration of the sorting system into existing upstream and downstream circuits.

- Ancillary equipment: The need for feed preparation and particle-stream handling.

- Operational issues: Performance, maintenance and training/expertise requirements.

\section{Acknowledgement}

The authors thank New Afton and New Gold for supporting the cave to mill research. Also, the authors thank ALS Metallurgy in Kamloops, MineSense Technologies and Scantech Pty Ltd for their technical support. The project was supported by the Natural Sciences and Engineering Research Council of Canada from their Collaborative Research and Development Grant Program (Grant No. 11 R74149 titled 'Mine-to-Mill Integration for Block Cave Mines'). 


\section{References}

Albanese, T \& McGagh, J 2011, 'Future trends in mining', in P Darling (ed.), SME Mining Engineering Handbook, 3rd edn, Society for Mining, Metallurgy and Exploration, Englewood.

Duffy, K, Valery, W, Jankovic, A \& Holtham P 2015, 'Integrating bulk ore sorting into a mining operation to maximise profitability', in D Pollard, G Dunlop \& P Cameron (eds), Proceedings of MetPlant 2015: Metallurgical Plant Design and Operating Strategies - World's Best Practice, The Australasian Institute of Mining and Metallurgy, Melbourne.

Elshkaki, A, Graedel, TE, Barbara, LC \& Reck, K 2016, 'Copper demand, supply, and associated energy use to 2050', Global Environmental Change, vol. 39, pp. 305-315.

Erdenebat, E 2017, Study of New Afton Ore Heterogeneity and its Amenability to Sensor Based Ore Sorting, MSc thesis, The University of British Columbia, Vancouver.

Gy, P 1995, 'Introduction to the theory of sampling I. Heterogeneity of a population of uncorrelated units', Trends in Analytical Chemistry, vol. 14, no. 2, pp. 67-76.

Hengemuhle, I, Klein, B \& Bamber, A 2017, Pilot Study of MineSense Shovel Sensing System for a Low Grade Copper Ore, Engineering report, The University of British Columbia, Vancouver.

Klein, B \& Bamber, B 2018, 'Mineral sorting', SME Mineral Processing \& Extractive Metallurgy Handbook, to be published.

Kurth H 2017, 'Suitability of on-belt elemental analysis for real-time ore quality measurement and bulk sorting', Proceedings of the 49th Conference of Metallurgists, Canadian Institute of Mining, Metallurgy and Petroleum, Westmount.

McKee, DJ, Chitombo, GP \& Morrell, S 1995, 'The relationship between fragmentation in mining and comminution circuit throughput', Minerals Engineering, vol. 8, no. 11, pp. 1265-1274, https://dx.doi.org/10.1016/0892-6875(95)00094-7

MineSense 2018a, ShovelSense, apparatus, http://minesense.com/shovelsense/

MineSense 2018b, BeltSense, apparatus, http://minesense.com/beltsense/

Nadolski, S, Klein, B, Elmo, D \& Scoble, M 2015, 'Cave-to-Mill: a Mine-to-Mill approach for block cave mines', Mining Technology, vol. 124, no. 1, pp. 47-55.

Nadolski, S, Klein, B, Elmo, D, Scoble, M, Liu, Y \& Scholar, J 2016, 'Investigation into the implementation of sensor-based ore sorting systems at a block caving operation', Proceedings of MassMin 2016, The Australasian Institute of Mining and Metallurgy, Melbourne, pp. 393-399.

Nadolski, S, Samuels, M, Klein, B \& Hart, C 2017, 'Evaluation of bulk and particle sensor-based sorting systems for the New Afton block caving operation', Minerals Engineering, vol. 121, pp. 169-179.

Peele, R 1918, Mining Engineers' Handbook, 1st Edition, John Wiley \& Sons Inc, New York.

Scantech 2018, GEOSCAN, apparatus, Scantech, Camden Park, https://www.scantech.com.au/product/geoscan/ 
